\title{
Lack of allozyme variation in the two carnivorous, terrestrial herbs Utricularia bifida and Utricularia caerulea (Lentibulariaceae) co-occurring on wetlands in South Korea: Inference of population history
}

\author{
Mi Yoon Chung, Jordi López-Pujol ${ }^{1}$ and Myong Gi Chung* \\ Division of Life Science and the Research Institute of Natural Science, Gyeongsang National University, Jinju 52828, Korea \\ ${ }^{1}$ BioC-GReB, Botanic Institute of Barcelona (IBB-CSIC-ICUB), Passeig del Migdia s/ $n$, Barcelona 08038, Spain
}

(Received 4 December 2017; Revised 21 December 2017; Accepted 22 December 2017)

\section{한반도 남부 지방 습지에 같이 자생하는 식충 육상 초본 2종 땅귀개 및 이삭귀개 (통발과)의 알로자임 변이의 결여: 집단의 역사 추론}

\author{
정미윤 · Jordi López-Pujol' 정명기* \\ 경상대학교 생명과학부 및 기초과학연구소, ${ }^{1} \mathrm{BioC}-\mathrm{GReB}$, 바르셀로나식물원연구소
}

\begin{abstract}
In central and southern Korea, the two small insectivorous, terrestrial herbs, Utricularia bifida and $U$. caerulea, often co-occur at wet locations (or in wetlands). The Korean Peninsula (with central China and northern Japan) constitutes the northern edge of their distribution, as their main range is subtropical and tropical Asia. The Korean populations of both species are very likely of post-glacial origin, given that warm-temperate vegetation was absent from the Korean Peninsula during the Last Glacial Maximum. Two hypotheses of the post-glacial colonization of the peninsula can be formulated; first, if current populations were founded by propagules coming from a single ancestral population (i.e., a single refugium), we would expect low levels of genetic diversity. Alternatively, if contemporary Korean populations originated from multiple sources (multiple refugia), we would expect high levels of genetic variation. To test which is more likely, we surveyed the degree of allozyme variation at 20 loci in ten populations for each of the two species from southern Korea. We found no allozyme variation within each species. However, their aquatic congener $U$. australis exhibited allozyme polymorphism across Japan (four polymorphic loci at three enzyme systems). We suggest that southern Korean populations of Utricularia bifida and U. caerulea were established by a single introduction event from a genetically depauperate ancestral population.
\end{abstract}

Keywords: genetic diversity, genetic monomorphism, post-glacial origin, terrestrial bladderworts

적 요: 한반도 중부 및 남부에 작은 육상성 식충식물(땅속줄기에서 벌레잡이주머니 존재)인 땅귀개와 이삭 귀개가 종종 습한 장소(또는 습지 내)에서 같이 서식한다. 이들 2 종은 아열대 및 열대 아시아의 주요 산지이 기 때문에 한반도는 중국 중부 및 일본 북부 지역과 더불어 분포의 북방한계이다. 최후의 빙하기 최대 기간 동안 따뜻한 온대 식물이 한반도에 없다는 점을 감안할 때 두 종의 한반도 집단은 빙하기 이후에 기원했을 가능성이 매우 높다. 한반도에서 빙하기 이후 정착에 대한 두 가설을 제시할 수 있다. 첫째로, 현재 집단이 단일 조상 개체군(즉, 하나의 피난처)으로부터 유래된 자손에 의해 형성되었다면, 우리는 낮은 수준의 유전 적 다양성을 기대할 것이다. 반면에, 현재 한반도 집단이 여러 집단(몇 곳의 피난처)에서 유래되었다면, 우리

\footnotetext{
*Author for correspondence: mgchung@gnu.ac.kr
} 
는 높은 수준의 유전적 변이를 기대할 수 있다. 어떤 가설이 더 타당한지를 검증하기 위해, 저자들은 한반도 남부지방 10 곳 지역을 대상으로 알로자임 변이를 조사하였다. 저자들은 각 종 내에서 알로자임 변이가 없음 을 발견했다. 그러나, 기존 연구된 그들의 수생 동속종인 Utricularia australis는 일본 전 지역을 대상으로 채 집된 자료에서 알로자임 다형성을 보였다(3개의 효소 시스템에서 4개의 다형성 좌위가 보고됨). 저자들은 땅 귀개와 이삭귀개가 남한으로 각각 개체군이 유전적 다양도가 낮은 조상집단에서 한번 도입되었을 가능성을 제안한다.

주요어: 유전적 다양성, 유전적 단형성, 빙하 이후 기원, 육상 통발종

On the southern Korean Peninsula, there are many wet places on hillsides, that range from very small $\left(<10 \mathrm{~m}^{2}\right)$ to medium $\left(50,000-100,000 \mathrm{~m}^{2}\right)$ sizes. The small-sized wet places usually occur at low elevations, and are largely located in southwestern Korea, concentrating in Haenam County (Jeollanam-do); in contrast, medium-sized mountain wetlands are generally found at elevations around 1,000 m (e.g., Mujechi-neup, Danjo-neup, and Hwaeom-neup), and mainly occur along the southern part of the "Nakdongjeongmaek" mountain range in southeastern Korea. These wetlands contribute significantly to local biodiversity with a unique species composition (Denny, 1994; Halls, 1997) that frequently include orchids (e.g., Epipactis thunbergii, Pogonia japonica, and Habenaria linearifolia) and other interesting herbs (Utricularia bifida, U. caerulea, $U$. yakusimensis, Drosera rotundifolia, Iris ensata var. spontanea, Parnassia palustris, Hypericum laxum, Moliniopsis japonica, Carex spp., Juncus effusus, etc.) (Lee, 2007; M. Y. Chung and M. G. Chung, pers. obs.)

Life-history traits but also historical factors influence genetic diversity found within species and populations (Gray, 1996). As congeners share recent evolutionary history and typically have similar life history characteristics ("phylogenetic inertia") (Morales, 2000; Losos, 2008), the direct comparisons between congeners allow to attribute any differences in genetic diversity to historical factors (Godt and Hamrick, 2001). With this in mind, Chung et al. (2013) surveyed allozyme variation in Korean populations of the two sundews Drosera peltata Thunb. var. nipponica (Masam.) Ohwi ex E. H. Walker (an element of the East Asian warm-temperate vegetation; the southern Korean Peninsula constitutes one of its northernmost limits) and $D$. rotundifolia $L$. (a widely distributed boreal species; the peninsula is one of its southernmost limits). While D. peltata var. nipponica showed no allozyme diversity, D. rotundifolia exhibited extremely low within-population variation $\left(H_{\mathrm{eP}}=\right.$ $0.005)$ and considerable among-population divergence $\left(F_{\mathrm{ST}}=\right.$ 0.817). The authors suggested that extant populations of $D$. peltata var. nipponica likely originated from a single ancestral population (from southern Japan or southern China) through post-glacial dispersal, whereas $D$. rotundifolia probably survived the Last Glacial Maximum (LGM) in situ on the Korean Peninsula.

Among the species listed above, we are interested in the two small, insectivorous herbs Utricularia bifida L. and U. caerulea L. One may expect similar levels of genetic diversity and patterns of genetic structure for these two congeners, as they co-occur and have similar breeding systems (both are selfcompatible) (M. Y. Chung and M. G. Chung, unpubl. data) and seed-dispersal mechanisms. Biogeographically, it is of interest to note that central Korea, together with central China and northern Japan, constitutes the northern limits of their distribution, as their main ranges are subtropical and tropical Asia (Bangladesh, Cambodia, India, Indonesia, Japan, Korea, Laos, Malaysia, Myanmar, Nepal, Philippines, Sri Lanka, Thailand, Vietnam), and other regions, including Australia, Madagascar (only for U. caerulea), Pacific islands (Guam, Palau) and Papua New Guinea (Li and Cheek, 2011). Thus, the extant Korean populations of both species are very likely of post-glacial origin, given that warm-temperate (or subtropical) vegetation was absent from the Korean Peninsula during the last glacial period (Chung et al., 2017a and references therein).

As for the sundew Drosera peltata var. nipponica on the Korean Peninsula (Chung et al., 2013), two scenarios can be proposed for the recent population history of the two terrestrial bladderworts $U$. bifida and U. caerulea: (1) if current Korean populations were founded by colonizers coming from a single glacial refugium, we would expect low (or extremely low) levels of genetic diversity within populations due to the longdistance dispersal associated with bottlenecks (Hewitt, 2000; Hu et al., 2009); (2) alternatively, if contemporary populations were derived from multiple source populations (multiple glacial refugia), we would expect high levels of within-population genetic variation-even if the source populations were genetically depauperate - as a consequence of the admixture of genetically divergent lineages arriving from different refugia (Petit et al., 2003). To test these alternative hypotheses, we surveyed allozyme variation at 20 loci in 10 populations for each of the two species from southern Korea. 


\section{Materials and Methods}

\section{Study species and population sampling}

Utricularia bifida is a small annual with traps $(0.5-1 \mathrm{~mm}$ long) on stolons and leaves. Inflorescences are erect and 2-40 $\mathrm{cm}$ long with 1-16 flowers. Corolla (6-10 mm long) is yellow, with a subulate spur as long as lower corolla lip. Capsules are broadly ellipsoid (2.5-3 mm long) and dorsiventrally compressed. Seeds are obliquely obovoid and $0.4-0.6 \mathrm{~mm}$ long ( $\mathrm{Li}$ and Cheek, 2011). Utricularia caerulea is also a small annual with traps $(0.2-1 \mathrm{~mm}$ long) on stolons and leaves. Inflorescences are erect and 5-44 cm long with 1-15 flowers. As one of the diagnostic characters, corollas (4-10 mm long) are violet, pink, or white. The spur is narrowly conic, usually longer than lower corolla lip. Capsules, similar to those of U. bifida, are also small and globose (1.5-2 $\mathrm{mm}$ long) and dorsiventrally compressed. Seeds are also tiny $(0.2-0.3 \mathrm{~mm}$ long) (Li and Cheek, 2011). Although Utricularia species are usually selfcompatible (Taylor, 1989; Araki and Kadono, 2003; Hobbhahn et al., 2006; Clivati et al., 2013), we do not know much about breeding systems of the two study species. Utricularia bifida and $U$. caerulea often co-occur in wet places and wetlands in southern Korea, where U. yakusimensis is rarely found, particularly in mountain wetlands along the southern "Nakdongjeongmaek" (J.-O. Hyun, pers. comm.).

In South Korea, U. bifida and U. caerulea have been listed as "LC" ("Least Concern") in the red list of threatened species (MOE, 2014), i.e., they are not considered endangered. However, U. bifida has been listed as "VU" ("Vulnerable") in the list of rare plants of Korea (KNA, 2012).

In proportion to total samples in each population, we randomly collected 341 individuals ( $U$. bifida) and 208 individuals ( $U$. caerulea) from 10 populations of each species from southern Korea (Fig. 1) in October 2007 and October 2008. The name of locations and sample sizes are included in the legend of Fig. 1.

\section{Enzyme electrophoresis}

Using a phosphate-polyvinylpyrrolidone buffer (Mitton et al., 1979), we extracted enzymes by finely cutting leaf samples

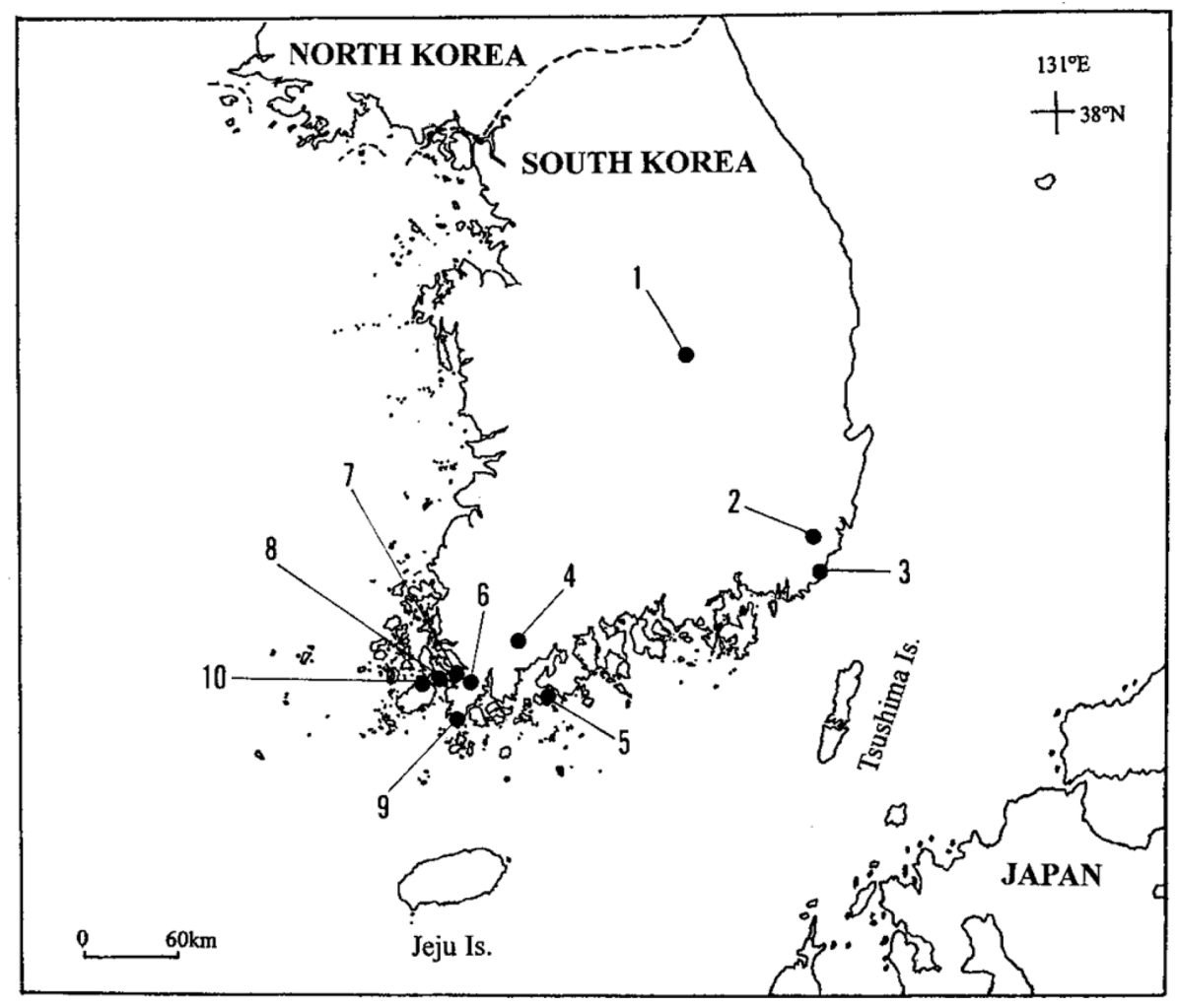

Fig. 1. The location and sample sizes of the 10 populations of Utricularia bifida (UB) and U. caerulea (UC) in southern examined in this study: 1, Sangju City (UB, $n=28 ; U C, n=36) ; 2$, Mujechi \# 4-neup in Mt. Jeongjok (UB, $n=26 ; U C, n=32) ; 3$, Gijang Town (UB, $n=13$; UC, $n=27) ; 4$, Hogye Township (UB, $n=25 ; \mathrm{UC}, \mathrm{n}=39$ ); 5, Geoguem Island (UB, $\mathrm{n}=22 ; \mathrm{UC}, \mathrm{n}=36$ ); 6, Hwasan Township (UB, $\mathrm{n}=17$; UC, $n=37) ; 7$, Hwangsan Township (UB, $n=20 ; \mathrm{UC}, \mathrm{n}=39$ ); 8, Munnae Township (UB, $\mathrm{n}=8 ; \mathrm{UC}, \mathrm{n}=15$ ); 9, Namchang Township (UB, $\mathrm{n}$ $=26 ; \mathrm{UC}, \mathrm{n}=32) ; 10$, Gunnae Township, Jin Island (UB, $\mathrm{n}=18 ; \mathrm{UC}, \mathrm{n}=32$ ). 
and then crushing them with a mortar and pestle. Enzyme extracts were absorbed onto $4 \times 6 \mathrm{~mm}$ wicks cut from Whatman 3MM chromatography paper, which were then stored at $-70^{\circ} \mathrm{C}$ until needed. Allozyme variation was assessed with horizontal starch-gel electrophoretic techniques. Starch gels $(13 \%)$ were stained for 13 enzyme systems: alcohol dehydrogenase (ADH, E.C.1.1.1.1), cathodal peroxidase (CPX, E.C.1.11.1.7), diaphorase (DIA, E.C.1.6.99.-), fluorescent esterase (FE, E.C.3.1.1.-), isocitrate dehydrogenase (IDH, E.C.1.1.1.42), leucine aminopeptidase (LAP, E.C.3.4.11.-), malate dehydrogenase (MDH, E.C.1.1.1.37), malic enzyme (ME, E.C.1.1.1.40), phosphoglucoisomerase (PGI, E.C.5.3.1.9), phosphoglucomutase (PGM, E.C.2.7.5.1), 6-phosphogluconate dehydrogenase (6PGD, E.C.1.1.1.44), shikimate dehydrogenase (SKDH, E.C.1.1.1.25), and triosephosphate isomerase (TPI, E.C.5.3.1.1). A modification (Haufler, 1985) of Soltis et al. (1983) system 6 was used to resolve ADH, CPX, DIA, FE, LAP, ME, PGI, PGM, and TPI. The morpholine citrate buffer system (pH 6.1) of Clayton and Tretiak (1972) was used to resolve IDH, MDH, 6PGD, and SKDH. Stain recipes were taken from Soltis et al. (1983), except DIA (Cheliak and Pitel, 1984). Putative loci were designated sequentially, with the most anodally migrating isozyme designated as ' 1 ' and the next ' 2 .' Alleles were also designated sequentially, with the most anodally migrating allele designated as ' $a$ ' the next ' $b$,' etc.

\section{Results}

For both Utricularia species, a total of 20 putative loci were resolved from the 13 enzyme systems: Adh, Cpx, Dia-1, Dia2, Fe, Idh-1, Idh-2, Lap, Mdh-1, Mdh-2, Me, 6Pgd-1, 6Pgd-2, Pgi-1, Pgi-2, Pgm-1, Pgm-2, Skdh, Tpi-1, and Tpi-2. The numbers of putative loci for each enzyme were within the range of the "typical" numbers of diploid plants (Gottlieb, 1982; Weeden and Wendel, 1989). Across the 20 putative loci resolved, we were unable to detect any genetic differences within the total samples of $U$. bifida and $U$. caerulea. Thus, the 20 putative loci were considered as monomorphic for the same allele in all the samples for each species; consequently, all the polymorphism indices, including the percentage of polymorphic loci $(\% P)$ and the total amount of genetic diversity (Nei's $\left.\mathrm{H}_{\mathrm{T}}[1973,1977]\right)$, were estimated to be zero in U. bifida and $U$. caerulea.

\section{Discussion}

\section{Lack of allozyme diversity in Utricularia bifida and $U$. caerulea: inference of population history}

Consistent with our first prediction, no allozyme variation was found in both species. Although this finding can be partially attributed to their shared phylogenetic, ecological, and life-history traits (they are congeners that usually co-occur, and both are self-compatible with similar seed-dispersal mechanisms), we believe that their lack of allozyme variation support the first scenario; extant Korean populations of $U$. bifida and $U$. caerulea would have been derived from a single refugial population (a different one for each species). The genetic monomorphism (that is, all loci fixed for the same allele at all populations) detected for both species suggests that contemporary populations would have been established (or recolonized) by a single introduction event from an ancestral population (perhaps located in southern Japan or in southern China) with low (or no) genetic variability (Chung et al., 2013 and references therein). The lack of genetic polymorphism at both $U$. bifida and $U$. caerulea is, in addition, unlikely attributable to a common trait of the whole genus; in other words, that the genus Utricularia originally had low genetic diversity. Araki (2000) examined allozyme variation in the common, aquatic bladderwort $U$. australis across Japan (except Hokkaido and Ryukyu Islands) and found four polymorphic loci (Adh, Pgi-2, Pgm-1, and Pgm-2) at three enzyme systems (ADH, PGI, and PGM) (Fig. 1 in Araki [2000]), suggesting that at least some species within the genus are not genetically depauperate.

How the two terrestrial bladderworts recolonized the Korean Peninsula from southern Japan, southern China, or, perhaps, Jeju Island (Fig. 1) remains a matter of debate. Nevertheless, seeds of Utricularia species are tiny $(0.2-0.6 \mathrm{~mm}$ long) and have large testa cells with a foveolate surface, features that are known to be favorable to the aggregation of air bubbles and thereby facilitating their floatability (i.e., increasing buoyancy in air or water) (Eriksson and Kainulainen, 2011; Menezes et al., 2014). Given these traits, it is likely that seeds were infrequently transported from southern Japan or southern China by strong gusts of wind (e.g., typhoons, which are very common in East Asia) from early summer to autumn, the flowering and fruiting time of $U$. bifida and U. caerulea. It is also possible that, for the case of the refugial population being located in southern China, seed transport to Korea was waterborne through the Kuroshio, the largest current in the Western Pacific (Chung et al., 2013). Although Kuroshio's flow into the Korean Peninsula was significantly reduced at the LGM, it increased progressively during the deglaciation until its current levels at the onset of the Holocene (Kao et al., 2006). Seed dispersal through this current would have been possible during most of the deglaciation period. 
Common features shared by plant taxa lacking allozyme variation on the Korean Peninsula

To date, studies on 16 plant taxa native to the Korean Peninsula that lack allozyme variation are available. In addition to the two Utricularia species studied herein, up to six orchid species (Habenaria dentata, Liparis pterosepala, Oreorchis coreana, Pecteilis radiata, Peristylus densus, and Tipularia japonica), plus the sundew Drosera peltata var. nipponica (Table 1) have a series of common features: (1) they are warmtemperate elements in East Asia (i.e., southern Korean
Peninsula is one of their northern limits), (2) they are rare within the peninsula (suggesting that the occurrence of these species in Korea might be the result of a rare event of longdistance seed dispersal), and (3) they have tiny, dust-like seeds (indicating a potential for long-distance dispersal) (reviewed in Chung et al., 2017b).

The other five orchid species listed in Table 1 (Cephalanthera subaphylla, Cypripedium japonicum, Epipactis papillosa, Goodyera repens, and Liparis kumokiri) are, in contrast, boreal and/or temperate elements of Northeastern Asia

Table 1. Plant taxa native in South Korea lacking allozyme diversity.

\begin{tabular}{|c|c|c|c|c|c|}
\hline Family & Species in South Korea $(\mathrm{R} / \mathrm{C})^{\mathrm{a}}$ & Ecol. affinity $/$ Range $^{\mathrm{c}}(\mathrm{C} / \mathrm{R})^{\mathrm{d}}$ & $\overline{N L^{\mathrm{e}}}$ & $\mathrm{NP}^{\mathrm{f}}$ & $\operatorname{Ref}^{g}$ \\
\hline Amaryllidaceae & Lycoris radiata var. radiata & T, WT/CSC, J, SK (C) & 24 & 8 & 1 \\
\hline Crassulaceae & Sedum sarmentosum & T, WT/C, K, J (C) & 15 & 10 & 2 \\
\hline Droceraceae & Drosera peltata var. nipponica $(\mathrm{R})$ & WT/CSC, SJ, SK (R) & 20 & 10 & 3 \\
\hline Lentibulariaceae & Utricularia bifida $(\mathrm{R})$ & $\begin{array}{l}\text { T, TR, WT/AUN, BA, CA, IN, IND, } \\
\text { J, K, LA, MA, NE, PH, PI, PNG, } \\
\text { SR, TH, VI (C) }\end{array}$ & 20 & 10 & 4 \\
\hline Lentibulariaceae & Utricularia caerulea $(\mathrm{R})$ & $\begin{array}{l}\text { T, TR, WT/AU, BA, CA, IN, IND, } \\
\text { J, K, LA, MA, MD, NE, PH, PI, } \\
\text { PNG, SR, TH, VI (C) }\end{array}$ & 20 & 10 & 4 \\
\hline Orchidaceae & Cephalanthera subaphylla $(\mathrm{R})$ & B, T/BH, EH, K, J, NEC, RFE (R) & 21 & 2 & 5 \\
\hline Orchidaceae & Cypripedium japonicum (R) & $\mathrm{T} / \mathrm{CC}, \mathrm{J}, \mathrm{K}(\mathrm{R})$ & 14 & 6 & 6 \\
\hline Orchidaceae & Epipactis papillosa $(\mathrm{R})$ & T/J, K, SLF (R) & 23 & 8 & 7 \\
\hline Orchidaceae & Goodyera repens $(\mathrm{R})$ & $\begin{array}{l}\text { B/BH, C, EU, IN, J, K, KAS, MY, } \\
\text { NA, NE, R, TW (C) }\end{array}$ & 19 & 3 & 5 \\
\hline Orchidaceae & Habenaria dentata $(\mathrm{R})$ & $\begin{array}{l}\text { Rarely T, TR, WT/CA, IN, LA, MY, } \\
\text { NE, SC, SJ, SK, TH, TW, VI (C) }\end{array}$ & 17 & 2 & 8 \\
\hline Orchidaceae & Liparis kumokiri $(\mathrm{C})$ & $\mathrm{B}, \mathrm{T} / \mathrm{J}, \mathrm{K}, \mathrm{RFE}(\mathrm{C})$ & 15 & 17 & 9,10 \\
\hline Orchidaceae & Liparis pterosepala (Jeju is.) (R) & WT/JJ (R) & 15 & 2 & 5 \\
\hline Orchidaceae & Oreorchis coreana $(\mathrm{R})$ & WT/JJ, SJT (R) & 17 & 4 & 11 \\
\hline Orchidaceae & Pecteilis $($ Habenaria) radiata $(\mathrm{R})$ & T, WT/ SK, J, WH (R) & 17 & 1 & 5 \\
\hline Orchidaceae & $\begin{array}{l}\text { Peristylus densus }(\mathrm{R}) \\
(=\text { Habenaria flagellifera })\end{array}$ & WT/JJ, SJ (R) & 17 & 1 & 5 \\
\hline Orchidaceae & Tipularia japonica $(\mathrm{R})$ & WT/SK, SJ (R) & 24 & 8 & 7 \\
\hline
\end{tabular}

${ }^{\mathrm{a}} \mathrm{R} / \mathrm{C}$, rare or common in South Korea that sampled for allozyme studies. ${ }^{\mathrm{b}}$ Ecological affinity: B, boreal; T, temperate; TR, tropical; WT, warm temperate (or subtropical). 'Distribution range: AUN, North Australia; AU, Australia; BA, Bangladesh; BH, Bhutan; C, China; CA, Cambodia; CSC, central and southern China; EH, eastern Himalayas; EU, Europe; IN, India; IND, Indonesia; J, Japan; JJ, Jeju Island, South Korea; K, Korea; KAS, Kashmir; LA, Laos; MA, Malaysia; MD, Madagascar; MY, Myanmar; NA, North America; NE, Nepal; NEC, northeastern China; PH, Philippines; PI, Pacific islands (Guam and Palau); PNG, Papua New Guinea; R, Russia; RFE, Russian Far East; SC, South China; SJ, southern Japan; SJT, Tochigi Prefecture in central Japan; SK, southern Korea; SLF, Fengcheng in southern Liaoning, northeastern China; SR, Sri Lanka; TH, Thailand; TW, Taiwan; VI, Vietnam; WH, western Henan, central China. ${ }^{\mathrm{d}} \mathrm{C} / \mathrm{R}$, common or rare at regional or global levels. ${ }^{\mathrm{N} L}$, number of loci examined. ${ }^{\mathrm{f}} \mathrm{NP}$, number of populations examined. ${ }^{\mathrm{g}}$ Source references: 1, Chung (1999); 2, Chung et al. (2016); 3 , Chung et al. (2013); 4, present study; 5, M. Y. Chung and M. G. Chung (unpubl. data); 6, Chung et al. (2009); 7, Chung (2009); 8, Chung et al. (in press); 9, Chung et al. (2005); 10, Chung et al. (2007); 11, Chung et al. (2012). 
(Chung et al., 2017b), and are also rare on the Korean Peninsula (except for L. kumokiri). We assume that these boreal and/or temperate orchid species, although likely managed to persist in situ on the Korean Peninsula at the LGM, would have done just in some favorable enclaves (microrefugia; Rull, 2009) (see Chung et al., 2017a, 2017b).

The two herbaceous perennials Lycoris radiata var. radiata and Sedum sarmentosum also lack allozyme variation (Table 1). The common features observed in these two plant taxa are triploidy (sterility) and, perhaps, a single introduction to the Korean Peninsula by vegetative means (e.g., bulbs for $L$. radiata var. radiata; shoots for $S$. sarmentosum).

In sum, the common features observed in the sexuallyreproducing 14 species (among them 11 are orchids) are largely responsible of their lack of allozyme variation, primarily through founder effects (e.g., post-glacial migration) and bottlenecks (e.g. survival in microrefugia). A future study adopting highly variable DNA and cpDNA markers (and, for warm-temperate or subtropical plant species, including samples from their LGM putative refugia) will be very useful to unravel the trajectories of population establishment and survival on the southern Korean Peninsula.

\section{Acknowledgments}

The authors thank John D. Nason and James L. Hamrick for discussing the scenarios for colonization histories of warmtemperate and subtropical plant species on the Korean Peninsula. This research was supported by Basic Science Program through the National Research Foundation of Korea (NRF-2017R1A2B4012215) funded by the Ministry of Education, Science and Technology to M.G.C.

\section{Literature Cited}

Araki, S. 2000. Isozyme differentiation between two infraspecies taxa of Utricularia australis R. Br. (Lentibulariaceae) in Japan. Acta Phytotaxonomica et Geobotanica 51: 31-36.

Araki, S. and Y. Kadono. 2003. Restricted seed contribution and clonal dominance in a free-floating aquatic plant Utricularia australis R. Br. in southwestern Japan. Ecological Research 18: 599-609.

Cheliak, W. M. and J. A. Pitel. 1984. Technique for Starch Gel Electrophoresis of Enzyme from Forest Tree Species. Information Report PI-X-42. Petawawa National Forestry Institute, Chalk River, ON, 49 pp.

Chung, M. G. 1999. Notes on allozyme variation in Lycoris radiata (Amaryllidaceae) from Korea. Botanical Bulletin of Aca- demia Sinica 40: 227-230.

Chung, J. M., K. W. Park, C.-S. Park, S.-H. Lee, M. G. Chung and M. Y. Chung. 2009. Contrasting levels of genetic diversity between the historically rare orchid Cypripedium japonicum and the historically common orchid Cypripedium macranthos in South Korea. Botanical Journal of the Linnean Society 160 : 119-129.

Chung, M. Y. 2009. Lack of allozyme diversity in populations of the rare, endangered terrestrial orchids Tipularia japonica and Epipactis papillosa in Korea. Plant Systematics and Evolution 278: 203-209.

Chung, M. Y., J. López-Pujol and M. G. Chung. 2013. Population history of the two carnivorous plants Drosera peltata var. nipponica and Drosera rotundifolia (Droseraceae) in Korea. American Journal of Botany 100: 2231-2239.

Chung, M. Y., J. López-Pujol and M. G. Chung. 2016. Notes on genetic variation in Sedum sarmentosum (Crassulaceae): Implications for the origin of southern Korean populations. Korean Journal of Plant Taxonomy 46: 371-377.

Chung, M. Y., J. López-Pujol and M. G. Chung. 2017a. The role of the Baekudaegan (Korean Peninsula) as a major glacial refugium for plant species: A priority for conservation. Biological Conservation 206: 236-248.

Chung, M. Y., J. D. Nason and M. G. Chung. 2005. Patterns of hybridization and population genetic structure in the terrestrial orchids Liparis kumokiri and Liparis makinoana (Orchidaceae) in sympatric populations. Molecular Ecology 14: 43894402.

Chung, M. Y., C.-W. Park, E. R. Myers and M. G. Chung. 2007. Contrasting levels of genetic diversity between the common, self-compatible Liparis kumokiri and rare, self-incompatible Liparis makinoana (Orchidaceae) in South Korea. Botanical Journal of the Linnean Society 153: 41-48.

Chung, M. Y., J. López-Pujol, M. Maki, K.-J. Kim, J. M. Chung, B.-Y. Sun and M. G. Chung. 2012. Genetic diversity in the common terrestrial orchid Oreorchis patens and its rare congener Oreorchis coreana: inference of species evolutionary history and implications for conservation. Journal of Heredity 103: 692-702.

Chung, M. Y., J. López-Pujol, S. Son, G. U. Suh, T. Yukawa and M. G. Chung. 2017b. Patterns of genetic diversity in rare and common orchids focusing on the Korean Peninsula: Implications for conservation. The Botanical Review. Advanced online publication. https://doi.org/10.1007/s12229-017-9190-5.

Chung, M. Y., H. T. Q. Le, S. Son and M. G. Chung. In press. Genetic diversity of the extremely rare Habenaria dentata and the rare Habenaria linearifolia (Orchidaceae) in South Korea: implications for population history and conservation. Plant 
Ecology and Evolution.

Clayton, J. W. and D. N. Tretiak. 1972. Amine-citrate buffers for $\mathrm{pH}$ control in starch gel electrophoresis. Journal of the Fisheries Research Board of Canada 29: 1169-1172.

Clivati, D., G. D. Cordeiro, B. J. Płachno and V. F. O. de Miranda. 2013. Reproductive biology and pollination of Utricularia reniformis A. St.-Hil. (Lentibulariaceae). Plant Biology 16: 677-682.

Denny, P. 1994. Biodiversity and wetlands. Wetlands Ecology and Management 3: 55-61.

Eriksson, O. and K. Kainulainen. 2011. The evolutionary ecology of dust seeds. Perspectives in Plant Ecology, Evolution and Systematics 13: 73-87.

Godt, M. J. W. and J. L. Hamrick. 2001. Genetic diversity in rare southeastern plants. Natural Areas Journal 21: 61-70.

Gottlieb, L. D. 1982. Conservation and duplication of isozymes in plants. Science 216: 373-380.

Gray, A. 1996. Genetic diversity and its conservation in natural populations of plants. Biodiversity Letters 3: 71-80.

Halls, A. J. 1997. Wetlands, Biodiversity and the Ramsar Convention: The Role of the Convention on Wetlands in the Conservation and Wise Use of Biodiversity. Ramsar Convention Bureau, Gland, Switzerland, 168 pp.

Haufler, C. H. 1985. Enzyme variability and modes of evolution in Bommeria (Pteridaceae). Systematic Botany 10: 92-104.

Hewitt, G. 2000. The genetic legacy of the Quaternary ice ages. Nature 405: 907-913.

Hobbhahn, N., H. Küchmeister and S. Porembski. 2006. Pollination biology of mass flowering terrestrial Utricularia species (Lentibulariaceae) in the Indian Western Ghats. Plant Biology 8: 791-804.

Hu, F. S., A. Hampe and R. J. Petit. 2009. Paleoecology meets genetics: deciphering past vegetational dynamics. Frontiers in Ecology and the Environment 7: 371-379.

Kao, S. J., C.-R. Wu, Y.-C. Hsin and M. Dai. 2006. Effects of sea level change on the upstream Kuroshio Current through the Okinawa Trough. Geophysical Research Letters 33: L16604.

KNA (Korea National Arboretum). 2012. Rare Plants in Korea. Korea National Arboretum, Pocheon, 412 pp. (in Korean)

Lee, M. 2007. Present status and conservation strategy of the mountainous wetlands in Ulsan city and Gyeongsangnamdo Province. Master's Thesis in Biology Education, Gyeongsang National University, Jinju, South Korea, 51 pp. (in Korean with English summary)
Li, Z. and M. R. Cheek. 2011. Utricularia Linneaeus. In Flora of China, Vol. 19. Cucurbitaceae through Valerianaceae, with Annonaceae and Berberidaceae. Wu, Z.-Y., P. H. Raven and D. Y. Hong (eds.), Science Press, Beijing and Missouri Botanical Garden Press, St. Louis, MO. Pp. 481-491.

Losos, J. B. 2008. Phylogenetic niche conservatism, phylogenetic signal and the relationship between phylogenetic relatedness and ecological similarity among species. Ecology Letters 11: 995-1003.

Menezes, C. G., E. C. Gasparino, P. C. Baleeiro and V. F. O. de Miranda. 2014. Seed morphology of bladderworts: A survey on Utricularia sect. Foliosa and sect. Psyllosperma (Lentibulariaceae) with taxonomic implications. Phytotaxa 167: 173182.

Mitton, J. B., Y. B. Linhart, K. B. Sturgeon and J. L. Hamrick. 1979. Allozyme polymorphisms detected in mature needle tissue of ponderosa pine. Journal of Heredity 70: 86-89.

MOE (Ministry of Environment, Republic of Korea). 2014. Korean Red List of Threatened Species. 2nd ed. National Institute of Biological Resources, Incheon, $242 \mathrm{pp}$.

Morales, E. 2000. Estimating phylogenetic inertia in Tithonia (Asteraceae): a comparative approach. Evolution 54: 475-484.

Nei, M. 1973. Analysis of gene diversity in subdivided populations. Proceedings of National Academy of Sciences of the United States of America 70: 3321-3323.

Nei, M. 1977. F-statistics and analysis of gene diversity in subdivided populations. Annals of Human Genetics 41: 225-233.

Petit, R. J., I. Aguinagalde, J.-L. de Beaulieu, C. Bittkau, S. Brewer, R. Cheddadi, R. Ennos, S. Fineschi, D. Grivet, M. Lascoux, A. Mohanty, G. Müller-Starck, B. Demesure-Musch, A. Palmé, J. P. Martín, S. Rendell and G. G. Vendramin. 2003. Glacial refugia: hotspots but not melting pots of genetic diversity. Science 300: 1563-1565.

Rull, V. 2009. Microrefugia. Journal of Biogeography 36: 481484.

Soltis, D. E., C. H. Haufler, D. C. Darrow and G. J. Gastony. 1983. Starch gel electrophoresis of ferns: a compilation of grinding buffers, gel and electrode buffers, and staining schedules. American Fern Journal 73: 9-27.

Taylor, P. 1989. The Genus Utricularia: A Taxonomic Monograph. The Royal Botanic Gardens, Kew, London, 724 pp.

Weeden, N. F. and J. F. Wendel. 1989. Genetics of plant isozymes. In Isozymes in Plant Biology. Soltis, D. E. and P. S. Soltis (eds.), Dioscorides Press, Portland. Pp. 46-72. 